\title{
Çeviri Eğitiminde Proje Temelli Bir Uygulama: Barış İçin Müzik Vakfı ve Altyazı Çevirisi
}

\section{A Project Based Practice in Translation Education: Music for Peace Foundation and Subtitling}

Araştırma/Research

\section{Deniz KURMEL}

Dr., Yıldız Teknik Üniversitesi, Fen-Edebiyat Fakültesi, Fransızca Mütercim ve Tercümanlık Anabilim Dalı, denkocak@yahoo.fr, ORCID ID: orcid.org/0000-0002-1041-5926

\section{ÖZET}

Yıldız Teknik Üniversitesi Fransızca Mütercim ve Tercümanlık Anabilim Dalı'nda MTF2391 kodlu Teknik Metin Yazarlığı dersi kapsamında, 2020-2021 akademik yılı güz yarıyılında, Barış İçin Müzik Vakfıyla birlikte altyazı çevirisi projesi yürütülmüştür. Proje kapsamında, Leonard Bernstein'ın "Young People's Concert" adlı video serisinin ilki olan “How Does Music Mean?" adlı videonun Türkçe altyazı çevrisi, Teknik Metin Yazarlığı dersi öğrencileri tarafından yapıımıştır. Bu çalışmada, çeviri eğitiminde sosyal yapılandırmacı yaklaşıma (Kiraly, 2000) dayanan proje tabanlı çeviri eğitimi yaklaşımları ve altyazı çevirisi yaklaşımları yol gösterici olmaktadır. Söz konusu projenin aşamaları, öğrencilerin görevlendirilmeleri ve görev tanımları, altyazı çevirisine yönelik alınan kararlar ve altyazı çevirisi uygulaması olarak sunulmaktadır. Proje kapsamında, öğrenciler, proje koordinatörü, editör, redaktör, çevirmen ve altyazı sorumlusu gibi farklı görevler almaktadır. Buna göre, dört adet çeviri grubu oluşturulmuştur. Her çeviri grubunda üç adet çevirmen ve bir adet redaktör yer almaktadır. İki editörün her biri iki tane çeviri grubundan sorumludur. Projenin genel olarak yürütülmesinden sorumlu iki proje koordinatörünün her biri, iki çeviri grubu ve onlarla bağlantılı bir editörle daha yakından çalışmaktadır. Çeviri gruplarının gerçekleştirdiği ve kontrol aşamaları tamamlanan çeviriler, altyazı formatına aktarılması amacıyla altyazı sorumlularına teslim edilmektedir. Öğrenciler farklı görevler alarak çeviriye yönelik farklı becerileri kazanmakta ve ekip çalışmasında, etkileşimli bir ortamda, gerçek bir çeviri sürecini deneyimlemektedir. Öğrenciler altyazı çevirisine yönelik olarak ise temel ilkeleri kazanırken teknolojiyle entegre bir şekilde çalışarak altyazı çevirisi programlarında çalışma becerisini de elde etmektedir.

Anahtar Sözcükler: çeviri eğitimi, sosyal yapılandırmacı yaklaşım, proje tabanlı çeviri eğitimi, altyazı çevirisi, çeviri projesi 


\section{ABSTRACT}

In the fall semester of the 2020-2021 academic year, a subtitling project was carried out with the Music for Peace Foundation within the scope of the MTF2391 Technical Writing course at Yıldız Technical University, Department of French Translation and Interpretation. As part of the project, the students of the Technical Writing course subtitled into Turkish the first video, "How Does Music Mean?" of Leonard Bernstein's "Young People's Concert" video series. In this study, project-based translation training approaches, which are based upon social constructivist translation education, (Kiraly, 2000), and subtitling approaches are employed. The phases of this project, in this article, are presented as the assignments and job descriptions of students, subtitling decisions, and subtitling practice. In the project, students take on different tasks such as being the project coordinator, editor, proofreader, translator, and subtitler. Accordingly, four translation groups were constituted. There are three translators and one proofreader in each translation group. Each of the two editors is responsible for two translation groups, and each of the two project coordinators is responsible for the overall process of the project and work more closely with the two translation groups and an associated editor. After the translations and revisions are completed, translated texts are delivered to the subtitler to be converted to the subtitle format. Working in a teamwork, students gain different translation skills by taking on different tasks, and experience a real translation process in an interactive environment. While students gain the basic principles for subtitling, they also take up the opportunity to work with subtitling programs with a technology integrated learning approach.

Keywords: translation training, social constructivist approach, project-based translation training, subtitling, translation project

\section{Giriş}

Günümüzde çeviribilim bölümleri, çeviri piyasasının gereksinimleri doğrultusunda ders programlarında ve ders içeriklerinde güncellemeye gitmektedir. Uzmanlık alanlarında çeviriye yönelik olarak teknik çeviri, özel alan çevirisi, teknik metin yazarlığı, terimbilim, bilgisayar destekli çeviri programları, proje yönetimi gibi dersler sunulmaktadır. Bu bağlamda, Yıldız Teknik Üniversitesi, Batı Dilleri ve Edebiyatları Bölümü, Fransızca Mütercim ve Tercümanlık Anabilim Dalında MTF2391 kodlu Teknik Metin Yazarlığı dersi Mesleki Seçmeli ders olarak kurgulanmıştır.

Teknik Metin Yazarlığı dersinde, teknik metin türlerini ve teknik metin oluşturma yöntemlerini öğrencilere uygulamalı olarak açıklayarak teknik metin yazımına ve teknik metin çevirisine temel oluşturulması hedeflenmektedir. 2020-2021 akademik yılı güz yarıyılında, söz konusu ders kapsamında Barış İçin Müzik Vakfı ile birlikte bir altyazı çevirisi projesi gerçekleştirilmiştir. Barış İçin Müzik Vakfı, İnsan Hakları Evrensel Beyannamesi'nin 27. maddesi olan; “Herkes, topluluğun kültürel yaşamına özgürce katılma, sanattan yararlanma ve bilimsel gelişmeye katılarak onun yararlarını paylaşma hakkına sahiptir" düşüncesinden hareketle 2005 yılında faaliyetlerine başlamıştır. Buna göre, Vakıf kuruluşundan itibaren, müzik eğitimi alma olanağı olmayan çocuklara, yaşadıkları mahallelerde, herhangi bir yetenek sınavı yapmadan ücretsiz, kaliteli çoksesli müzik eğitimi sunmayı amaçlamaktadır.

Vakıf, Covid-19 Pandemi döneminde uzaktan eğitime geçtiğinden dijital müzik eğitimine yönelik kaynaklara gereksinim duymuştur. Bu amaçla, besteci, orkestra şefi, 
piyanist ve aynı zamanda müzik eğitmeni kimliği de bulunan Leonard Bernstein'ın "Young People's Concert" adlı video serisinin Türkçe altyazı çevirisinin yapılmasına karar verilmiştir. Söz konusu video serisinin ilki olan "How Does Music Mean?" adlı videonun Türkçe altyazı çevrisi Teknik Metin Yazarlığı dersi kapsamında gerçekleştirilmiştir.

Bu çalışmada, Teknik Metin Yazarlığı dersinin, söz konusu videonun Türkçe altyazı çevirisinin gerçekleştirilmesine yönelik olarak Barış İçin Müzik Vakfı ile birlikte projelendirilmesi ele alınmaktadır. Proje tabanlı çeviri eğitimi yaklaşımları, altyazı çevirisine yönelik yaklaşımlar ve gönüllü çevirmenlik kavramı dersin altyazı çevirisine yönelik olarak projelendirilmesinde yol gösterici olmaktadır.

\subsection{Barış İçin Müzik Vakfı}

Dersin projelendirmesine yönelik detayları aktarmadan önce Barış İçin Müzik Vakfı'nı daha yakından tanımak yerinde olacaktır. 2005 yılında, mimar Mehmet Selim Baki ve akademisyen Yeliz Baki herkesin kültürel yaşama katılabilmesi, sanattan yararlanabilmesi düşüncesinden hareketle Barış İçin Müzik Vakfı'nın temellerini atmıştır. Bu hedef doğrultusunda, 2005 yılında, Edirnekapı'da yer alan Ulubatlı Hasan İlköğretim Okulu'nda ilk müzik atölyesi kurularak öğrencilere ücretsiz olarak akordeon ve solfej eğitimleri verilmeye başlanmıştır. Eğitim modeli olarak, en başından itibaren yetenek seçmesinin yapılmadığı, istekli olan her çocuğun katılabildiği, gönüllülük esasına dayalı bir eğitim modeli benimsenmiştir. 2009 yılından itibaren, Barış İçin Müzik girişimi farklı ilköğretim okullarının bünyesinde de müzik eğitimi vermeye başlamıştır.

Urban Age Projesi ${ }^{1}$ kapsamında, dünyanın önde gelen metropollerinde halkın katılımı ile gerçekleşen kentsel projelere verilen "Uluslararası Deutsche Bank Urban Age Ödülü", 2009 yılında Barış İçin Müzik girişimine verilmiştir. Barış İçin Müzik girişimi, 2011 yılında vakıf kimliğini alarak çalışmalarını Edirnekapı'daki vakıf binasına taşımıştır. Yine aynı yıl, mümkün olabildiğince çok sayıda çocuğu ve genci müzikle buluşturmaya dayanan sosyal dönüşüm hareketi El Sistema2'nın kurucusu José Antonio Abreu, İstanbul Kültür Sanat Vakfı'nın girişimiyle Barış İçin Müzik Vakfı’nı ziyaret etmiştir. 2014 yılında ise, iki kurum arasında imzalanan "Dostluk Antlaşması" ile Barış İçin Müzik, "El Sistema Türkiye" olarak tanınmıştır.

Akordeonla çalışmalarına başlayan Barış İçin Müzik eğitiminin bünyesinde, günümüzde, tüm yaylılar, bakır üflemeliler, klavyeler, üflemeliler ve perküsyonlar yer almaktadır. Bu enstrümanların onarım ve bakımının yapılabilmesi için, vakfın bünyesinde bir lüthier atölyesi de kurulmuştur. Barış İçin Müzik Vakfı eğitim

\footnotetext{
${ }^{1}$ Urban Age Projesi, Deutsche Bank Alfred Herrhausen Society ve London School of Economics and Political Science işbirliği ile gerçekleştirilmektedir.

2 El Sistema; 1975 yılında Venezuelalı vizyoner, ekonomist, müzisyen José Antonio Abreu tarafından başlatılan bir sosyal dönüşüm hareketidir. Venezuela'da özellikle dezavantajlı bölgelerde yaşayan çocuklara ücretsiz müzik eğitimi sağlayarak onların suç ortamlarından uzaklaşmasını sağlayan, kişisel gelişimlerine katkıda bulunan bir programdır.
} 
çalışmalarına, kurduğu ilk adım, çocuk ve gençlik orkestralarıyla devam etmektedir. Edirnekapı'da başlayan girişim tekrarlanabilir olması sebebiyle Türkiye'nin başka şehirlerine de yayılmıştır.

Barış İçin Müzik Vakfı sağladığı karşılıksız müzik eğitimi ile büyüyen çocuklar ve gençler aracılığıyla barışçıl ortamların yaratımına katkı sunmayı hedeflemektedir. Vakıf fırsat eşitliği, demokratik ortam ve barış gibi savunduğu değerler doğrultusunda ürettiği içeriklerde, değerlerini yansıtan, samimi, içten bir dil kullanarak katılımı destekleyen, amaca hizmet eden mesajlar üretmeye dikkat etmektedir. ${ }^{3} \mathrm{Bu}$ doğrultuda, vakıf senedi, yıllık beyannameler, vakıf manifestosu, tanıtım metinleri, proje başvuru metinleri, faaliyet raporları, e-bültenler, sosyal medya post metinleri ve mektuplar üretilmektedir. Vakıf, bilginin görselleştirilerek paylaşılmasını önemsemektedir, ürettikleri metinler; yazı, video, görsel ve grafik birlikteliğine dayanmaktadır. Barış İçin Müzik Vakfı, El Sistema Avrupa'nın uluslararası kurucu üyesi olduğundan, metinlerinin Türkçe, İngilizce, İspanyolca ve Almanca üretilmesi önemlidir. Bu noktada her zaman çeviri desteğine gereksinim duymaktadır. Web sitesinin, video içeriklerinin başka dillere çevrilmesi Vakfın hedefleri arasında yer almaktadır.

\section{Yöntem}

Çalışmanın yöntemsel dayanağını proje tabanlı çeviri eğitimine ve altyazı çevirisine yönelik yaklaşımlar oluşturmaktadır. Günümüzde çeviri eğitiminde, çeviri alanının koşulları ve çeviri piyasasının gereksinimlerinden hareketle farklı bakış açıları benimsenmektedir. Piyasa gereksinimlerini dikkate alarak Gouadec (2002), çevirmenin araştırmacı, terminolog, editör, redaktör ve bilgisayar teknolojileri uzmanı gibi birçok farklı görevinin olduğuna vurgu yapmaktadır. Böylesi çok boyutlu bir donanıma sahip olması beklenen çevirmenlerin eğitimine yönelik olarak, sınıf ortamında piyasa koşullarının yaratılması önemlidir (Gouadec, 2003, s. 17).

Çeviri eğitiminde sosyal yapılandırmacı (social constructivist) bakış açısını savunan Kiraly (2000), çeviri eğitiminde işbirlikçi yaklaşıma ve bilginin karşılıklı olarak yaratılmasına vurgu yapmaktadır. Buna göre, öğrenci aktif bir konuma taşınarak bilgisini karşılıklı bir işbirliğiyle oluşturmaktadır. Kiraly, sosyal yapılandırmacı yaklaşımın temelinde, çeviri eğitiminde "gerçek proje çalışmaları" etrafında şekillenen bir "güçlenme" yaklaşımı önerdiğini vurgulamaktadır. Bununla esas amaçlanan, gerçek çeviri projelerinde, gerçek işverenlerle çalışma olanağı bulan öğrencilerin gerçek bir deneyim yaşayarak yarı profesyonel bir özerklik düzeyi kazanabilmesidir (Kiraly, 2005, s. 1102).

Kiraly, proje tabanlı öğrenme bağlamında, öğrencilerle farklı çalışmalar yürütmüştür. Proje çalışmalarından bir tanesi ise, 2004-2005 kış döneminde, ders kapsamında öğrencileriyle bir Alman yapım şirketi için bir belgeselin ingilizce altyazı

\footnotetext{
${ }^{3}$ Vakfın Genel Koordinatörü Nilgün Öztunalı Teknik Metin Yazarlığı dersi kapsamında yaptığı sunumda, ürettikleri teknik metinlerin özelliklerine değinmiştir. Vakfın ürettiği içeriklerin söylem boyutunda incelenmesi bu çalışmanın kapsamı dışında tutulmaktadır.
} 
çevirisini yapmak olmuştur. Kiraly, söz konusu proje çalışması sonucunda; öğrencilerin grup çalışmasını gerçek bir iş kapsamında, gerçek bir işverenle bağlantılı bir şekilde yürüterek temel ilkelerin kazanılmasına yönelik öğrenme, sosyo bilişsel öğrenme, etkileşimli öğrenme ve karşılıklı öğrenme olmak üzere çok boyutlu bir öğrenme gerçekleştirdiklerinin altını çizmektedir (2005, ss. 1106-1108).

Pym (2007), çeviri eğitiminde eğitim kurumlarının öğrencileri çevirmenin farklı profesyonel rollerine yönelik eğitmesinin önemini vurgulamaktadır. Bu bağlamda, proje yönetiminin öğretilmesinin ve öğrencilerin ekip çalışmasına katılımının sağlanmasının gerekliliğinin altını çizmektedir. Pym'e göre, proje yönetimine yönelik beceriler kuramsal boyutuyla aktarılabilir, ancak proje yönetiminin geliştirilmesi sınıf ortamında yürütülen gerçek projeler bağlamında mümkün olmaktadır. Pym, ders saatinde yürütülen hatta ders dışı saatlere de yayılan büyük projelerde farklı görev tanımlarıyla çalışan öğrencilerin, ekip çalışmasını uygulamayla öğrenilebileceğini belirtmektedir. Ayrıca ekip çalışması ne kadar çok uygulanırsa öğrenciler o oranda büyük ölçekli çeviri projelerinde yer almaya hazır duruma gelecektir (2007, s. 11).

Olvera-Lobo ve ekibinin (2005) ortaya attığı çeviri eğitiminde profesyonel yaklaşım, farklı projeler bağlamında takım çalışması simülasyonunu kullanarak çeviri eğitimine yeni bir soluk getirmektedir. Çeviri eğitiminde profesyonel yaklaşımın uygulaması olarak, Granada Üniversitesi Mütercim ve Tercümanlık Bölümünde Aula.int projesi yürütülmektedir. Proje kapsamında, öğrenciler farklı çalışmalarda farklı görevler üstlenerek çeviriye yönelik bir çok farklı görevi deneyimlemekte ve beceri kazanmaktadır (Labo vd., 2005, s. 140).

Uzmanlık alanlarında çeviri eğitiminde, sınıf ortamında gerçek çevri projeleri yürüten Galán-Mañas (2011), proje temelli eğitimin sadece çeviri yeterliliklerini geliştirmekle kalmayıp, özerk bir şekilde bir takım çalışmasında yer alma, bilgi ve iletişim teknolojilerini kullanabilme gibi genel yeterliliklerin kazanılmasına da katkı sağlayacağını belirtmektedir. Gerçek çeviri projelerinde çalışarak, öğrenciler öğrenme sürecinde aktif rol almakta, ekip çalışması yürütmekte, organizasyon ve karar alma becerilerini geliştirmektedir. Ayrıca profesyonel çevirmenlerin kullandığı yöntemler hakkında fikir sahibi olarak sınıf ortamında çeviri piyasasının koşullarını deneyimlemektedir (Galán-Mañas, 2011, s. 110).

Proje tabanlı çevri eğitiminin, Türkiye'de de bazı örnekleri mevcuttur. Demirel ve Sabaz (2021), Yıldız Teknik Üniversitesi, Fransızca Mütercim ve Tercümanlık Anabilim Dalında, 2019-2020 akademik yılı güz döneminde MTF4451 Teknik Çeviri 5 dersi kapsamında çeviri teknolojilerinin etkin kullanımıyla gerçekçi bir çeviri projesi yürütmüşlerdir. Söz konusu projede, dersin öğrencileri Yöresel Ürünler ve Coğrafi İşaretler Türkiye Araştırma Ağı'nın (YÜciTA) web sitesinde bulunan 6175 sözcük uzunluğundaki Türkçe içeriğin Fransızcaya çevirisini gerçekleştirmiştir (Demirel \& Sabaz, 2021, s. 39). Canım Alkan (2020) ise, İstanbul Üniversitesi İngilizce Mütercim ve Tercümanlık Anabilim Dalında yürüttüğü Proje (Seminer) dersinde proje tabanlı simülasyon yöntemine dayalı bir ders içeriği oluşturmuştur. Canım Alkan, yürüttüğü ders ile çeviri eğitiminde öğrenci güçlenmesine simülasyon yönteminin de katkı sağlayabileceğini göstermiştir (2020, s. 3932).

183 
Çeviri eğitiminde proje tabanlı kurgulanan ders içerikleri, öğrencilerin deneyimsel bir öğrenmeyle, öğrenmede aktif rol almalarına olanak sağlamaktadır. Proje çalışmalarında, çevirmen kimliğinin farklı boyutlarını deneyimleyen öğrenciler çeviri bağlamında farklı deneyimler kazanmaktadır. Bununla birlikte, gerçek projelerde görev alan öğrenciler, gerçek bir işverene karşı sorumluluk duyarak daha motive çalışmaktadır (Mackenzie, 2004, s. 36).

Proje tabanlı olarak yürütülen Teknik Metin Yazarlığı dersi kapsamında altyazı çevirisi gerçekleştirildiğinden altyazı çevirisine yönelik kavramlara da değinmek yerinde olacaktır. Okyayuz ve Kaya (2016) altyazı çevirisi derslerinin, proje tabanlı ve durumlu öğrenme odaklı eğitim için ideal uygulama ortamları oluşturduğunu belirtmektedir (2016, s. 266). Günümüzde, çeviribilim alanında görsel-işitsel çeviri alanında birçok çalışma yürütülmektedir (Gambier, 2006, 2008; Diaz-Cintas \& Anderman, 2009; Chaume, 2013; Chiaro, 2013; Okyayuz, 2016; Okyayuz \& Kaya, 2017). Genel tanımıyla, görsel-işitsel çeviri; görsel-işitsel metinlerin diliçi ve dillerarası aktarımıyla ifade edilen bir çeviri biçimidir (Chaume, 2013, s. 105). Görsel-işitsel çeviri türleri ve alt türleri konusunda da farklı görüşler mevcuttur, çeviribilimciler farklı bakış açılarından hareketle türleri farklı biçimlerde sınıflandırmaktadırlar. Altyazı Çevirisi adlı kitabında, Okyayuz , görsel-işitsel çeviri türlerini eşgöstergebilimsel görsel-işitsel çeviri türleri ve göstergelerarası görsel-işitsel çeviri türleri olmak üzere iki ana başlık altında ele almaktadır (2016, ss. 25-51). Altyazı çevirisi; işitselin görselle ya da görselin işitselle aktarımına dayanan göstergelerarası görsel-işitsel çeviri türü olarak ele alınmaktadır (Okyayuz, 2016, s.37).

Bu çalışma kapsamında ele alınan çeviri projesinde dillerarası altyazı çevirisi ekip çalışmasıyla gerçekleştirilmektedir. Bu bağlamda, Sánchez'in (2004) kendi profesyonel altyazı çevirisi şirketinde yürüttüğü ekip çalışma yöntemi yol gösterici olmaktadır. Buna göre Sánchez (2004);

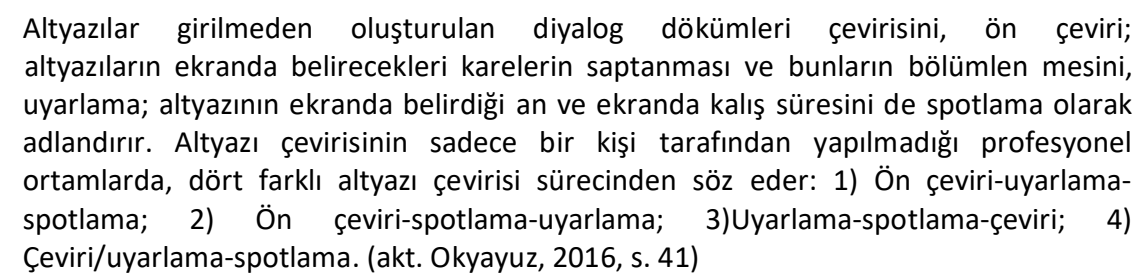

Çeviri alanında kullanılan teknolojilerin gelişmesiyle, altyazı çevirisi uygulamalarında teknolojinin kullanımı da önem kazanmıştır. Özellikle altyazı çevirisi eğitimine teknolojiyi entegre ederek altyazı programlarından yararlanmak önemlidir, hatta farklı altyazı çevirisi programları eğitim sürecinde ele alınabilir (Okyayuz \& Kaya, 2017, s. 324). İyi altyazı çevirisi uygulamaları için, altyazıya yönelik teknik ve dilsel bazı konulara açıklık getirilmesi de önemlidir. Bu doğrultuda ESIST (European Association for Studies in Screen Translation) bünyesinde hazırlanan kılavuz yol gösterici olmaktadır (Carroll \& Ivarsson, 1998). Söz konusu kılavuzda, sözdizimi kullanımı, başlangıç ve bitiş sürelerine yönelik spotlama işlemi, altyazı ve ses arasındaki uyuma yönelik senkronlama işlemi ve çeviri süreci gibi konularda bilgiler yer almaktadır. 
Altyazı çevirisi uygulaması bağlamında projelendirilen ders kapsamında, öğrenciler çevirmenlik mesleğine yönelik farklı becerileri edinirken, gönüllü çevirmen kimliğini de deneyimlemektedir. Barış İçin Müzik Vakfı, proje kapsamındaki işbirliği sürecinde öğrencileri "çeviri gönüllüleri” olarak tanımlamıştır. Bu bağlamda, gönüllü çevirmen kimliğiyle (Gambier, 2007, 2012) öğrenciler Vakfın savunduğu barış, demokratik ortam, fırsat eşitliği gibi değerlerin taşıyıcısı olmuştur. Çevirmenlerin, çeviri pratikleri aracılığıyla fırsat eşitliğine (Pérez González \& Saraeva, 2012) ve demokratikleşme hareketine (Bogenç Demirel \& Görgüler, 2015) katkı sunduğu çalışmalardan söz etmek mümkündür. Bu çalışmada ise öğrenciler, proje tabanlı altyazı çevirisiyle Vakfın dijital müzik eğitim materyaline katkı sağlamakta, böylelikle müzik eğitiminde fırsat eşitliğine ve müzik eğitimiyle demokratik ortamların yaratılmasına destek olmaktadır.

\section{Teknik Metin Yazarlığı Dersi}

MTF2391 kodlu Teknik Metin Yazarlığı dersi, Yıldız Teknik Üniversitesi, Batı Dilleri ve Edebiyatları Bölümü, Fransızca Mütercim ve Tercümanlık Anabilim Dalının eğitim programında, 3. yarıyıl mesleki seçmeli dersleri arasında yer almaktadır. 2020-2021 akademik yılı güz yarıyılında, söz konusu ders Covid-19 Pandemi süreci nedeniyle, YTÜ Eğitim Yönetim Sistemi (https://online.yildiz.edu.tr) aracılığıyla uzaktan eğitim modelinde yürütülmüştür.

Pek çok uluslararası kuruluşun işbirliği ile 1999 yılından itibaren Avrupa Yükseköğretim Alanı yaratmayı hedefleyen bir reform olan Bologna Süreci; yükseköğretim sistemlerinin kendilerine özgü farklılıkları korunarak birbirleriyle karşılaştırılabilir olmasını ve uyumlu hale getirilmesini amaçlamaktadır. Bu şekilde, bir ülkeden ya da yükseköğretim sisteminden bir diğerine geçişin kolaylaşması ve böylece öğrencilerin, öğretim görevlilerinin hareketliliğinin ve istihdamının artırılması planlanmaktadır. 2001 yılından itibaren Türkiye'de Bologna Sürecine katılım sağlamıştır. Bu doğrultuda, Yıldız Teknik Üniversitesi, Avrupa Yükseköğretim Yeterlilikler Çerçevesi ve Türkiye Yükseköğretim Yeterlilikler Çerçevesi uyarınca programlarını ve derslerini yeniden düzenlemiştir.

Bologna Süreci kapsamında, MTF2391 kodlu Teknik Metin Yazarlığı dersinin amacı, içeriği, öğrenim çıktıları, haftalık konuları, değerlendirme sistemi ve AKTS (Avrupa Kredi Transfer ve Toplama Sistemi) iş yükü belirlenmiştir. Teknik çeviriye ve teknik metin üretimine temel oluşturmak amacıyla söz konusu dersin içeriği; teknik metin türlerinin, teknik metin oluşturma yöntemlerinin öğrenciye anlatılmasına ve farklı uzmanlık alanlarında Fransızca ve Türkçe teknik metin yazma uygulamalarının yapılmasına dayanmaktadır. Dersin öğrenim çıktıları ise şöyledir:

- Teknik metnin özellikleri konusunda bilgi sahibi olma

- Teknik metin yazarının sahip olması gereken donanımlara yönelik bilgi sahibi olma

- Teknik metin oluşturmaya yönelik aşamaları uygulama becerisi

- $\quad$ Anadilinde ve çalışma dilinde teknik metin yazma becerisi 
- Teknik metin yazarlığına yönelik seçilen bir uzmanlık alanında proje yürütebilme becerisi

Öğrencilerin, ders kapsamında hedeflenen bilgi ve becerileri kazanabilmesine yönelik olarak ders planı oluşturulmuştur.

\section{Tablo 1}

MTF2391 Teknik Metin Yazarlığı 2020-2021 Öğrenim Planı

\begin{tabular}{|c|c|}
\hline Hafta & Konular \\
\hline 1 & Dersin tanıtımı \\
\hline 2 & Teknik metin nedir? Teknik metin yazarı kimdir? \\
\hline 3 & $\begin{array}{l}\text { Teknik metin oluşturma yöntemleri: Hazırlık- Araştırma - } \\
\text { Organizasyon aşamaları }\end{array}$ \\
\hline 4 & Teknik metin oluşturma yöntemleri: Yazım Aşaması \\
\hline 5 & Teknik metin oluşturma yöntemleri: Kontrol Aşaması \\
\hline 6 & $\begin{array}{l}\text { Teknik metin oluşturma yöntemlerinin uygulanması: STK } \\
\text { hakkında teknik metin oluşturmak, STK hakkında öğrenci } \\
\text { sunumları }\end{array}$ \\
\hline 7 & $\begin{array}{l}\text { Barış İçin Müzik Vakfı kurucularından Yeliz Baki ve Vakfın Genel } \\
\text { Koordinatörü Nilgün Öztunalı'nın Vakıfla ilgili sunumu }\end{array}$ \\
\hline 8 & Ara Sınav 1 \\
\hline 9 & $\begin{array}{l}\text { Barış İçin Müzik Vakfı ile yürütülecek projenin tanımı ve görev } \\
\text { dağılımı, "Leonard Bernstein" hakkında bilgi }\end{array}$ \\
\hline 10 & $\begin{array}{l}\text { Barış İçin Müzik Vakfı "Young's People Concert" serisinden "How } \\
\text { Does Music Mean?" videosunun altyazı projesi, Bülten1 }\end{array}$ \\
\hline 11 & $\begin{array}{l}\text { Projeye yönelik altyazı çevirisi hakkında Araş. Gör. Dr. Fulya } \\
\text { Marmara ve Araş. Gör. Onur Sabaz'ın sunumu }\end{array}$ \\
\hline 12 & Proje çalışması: Çeviri kontrolleri \\
\hline 13 & Proje çalışması: Çeviri kontrolleri \\
\hline 14 & Proje çalışması: Altyazı kontrolleri \\
\hline 15 & Final \\
\hline
\end{tabular}

Buna göre, ilk derslerde "Teknik Metin Nedir? Teknik Metin Yazarı Kimdir?" sorularından hareketle Teknik Metin Yazarlığına yönelik kavramlar üzerinde durulmaktadır. Teknik metin oluşturma aşamaları; hazırık, araştırma, organizasyon, yazma ve kontrol aşamaları (Gerald vd., 2015) öncelikli olarak kavramsal boyutta ele alınmaktadır. Öğrenciler ders dışında, bir uzmanlık alanında sözü edilen tüm aşamaları uygulayarak o alana yönelik teknik metinler oluşturmaktadır. 2020-2021 akademik yılında gerçekleştirilen ders kapsamında, Barış İçin Müzik Vakfı ile birlikte yürütülecek projeye hazırlık olması adına, öğrencilerin tamamı araştırma konusu olarak bir Sivil 
Toplum Kuruluşu seçmişlerdir. Seçtikleri STK'ya yönelik, ders kapsamında ele alınan teknik metin oluşturma aşamalarını takip ederek, farklı teknik metinler oluşturmuşlar ve bu içerikleri derste sunmuşlardır. Farklı STK'lara yönelik her çalışmanın derste sunulmasıyla, incelenen farklı kuruluşların amaçları, oluşturdukları içerikler ve benimsedikleri dil konusunda bilgi sahibi olunmuştur. Kavramsal ve uygulama boyutunda yürütülen derslerin devamında, 17 Kasım 2020 günü yapılan derse, Barış İçin Müzik Vakfı kurucularından Yeliz Baki ve Vakfın Genel Koordinatörü Nilgün Öztunalı, katılarak vakıflarının yapısını, amaçlarını ve vakıflarında metin/içerik üretimi çalışmalarının nasıl yürütüldüğünü sunmuşlardır. Böylelikle, öğrenciler Barış İçin Müzik Vakfı bünyesinde üretilen farklı teknik metinlere yönelik bilgi edinerek, gerçek ortamda bir STK bünyesinde teknik metin/içerik üretiminin nasıl gerçekleştirildiğini görme fırsatı yakalamışlardır. Bu dersten sonra, Barış İçin Müzik Vakfı'yla birlikte yürütülecek proje kurgulanarak proje çalışmalarına başlanmıştır.

\section{Teknik Metin Yazarlığı Dersinin Projelendirilmesi}

Barış İçin Müzik Vakfı, uzaktan müzik eğitimine yönelik ders materyali olarak Leonard Bernstein'ın "Young People's Concert" adlı video serisini kullanmaya karar vermiştir. Söz konusu video serisi, Bernstein tarafından New York Filarmoni Orkestrasıyla birlikte, 1958-1972 yılları arasında klasik müziği gençlere tanıtmak ve sevdirmek için gerçekleştirilen konser serisidir. Toplamda 53 konserden oluşan video serisi, Amerikan televizyonlarında yayımlanmış ve farklı ülkelerde de gösterilmiştir.

Vakıf yetkililerinin, 17 Kasım 2020 tarihinde, Teknik Metin Yazarlığı dersindeki sunumunun ardından Bernstein'ın eğitici müzik videolarının İngilizceden Türkçeye altyazı çevirisi projesinin yürütülmesine karar verilmiş ve dersi alan 22 öğrencinin tamamı altyazı çevirisi çalışmalarına destek vermek istediğini belirtmiştir. Ancak, bölümün birinci yabancı dili Fransızca olduğundan, Ingilizce çeviri çalışmalarında zorlanabileceğini belirten az sayıda öğrenci olmuştur. Bu öğrenciler de farklı görevleri rahatlıkla alabileceklerini belirtmiştir. Öğrencilerin tamamının gönüllü katılımı, dersin Barış için Müzik Vakfı'yla birlikte yürütülecek altyazı çevirisi projesine yönelik kurgulanmasını kolaylaştırmıştır.

Vakfın müzik ekibinin, dijital müzik eğitimine yönelik gereksinimleri doğrultusunda, öncelikli olarak Türkçe çevirisini talep ettikleri videoyu belirleme sürecinde, ders kapsamında projeye yönelik hazırlık çalışmalarına başlanmıştır. Projede çevirisi yapılacak alana yönelik bilgi edinilmesi amacıyla, Leonard Bernstein'ın kim olduğunu anlatan bir teknik metin üzerinde çalışılmıştır. Bu aşamada, projenin yürütülmesinde aktif rol alabilecek iki öğrenci; Melis Asya Meriç ve Gizem Büyükdöker ${ }^{4}$, diğer öğrencilerin de onayıyla proje koordinatörü seçilmiştir.

Barış İçin Müzik Vakfı müzik ekibi, serinin ilk performansı "What Does Music Mean?" adlı videoyu kendi ders içeriklerine öncelikli olarak katmaya karar vermiştir. Söz konusu videonun Youtube linki (https://youtu.be/_2OisC_XfF4), vakıf tarafından 4

\footnotetext{
${ }^{4}$ Çalışma kapsamında proje koordinatörü öğrencilerin onanmış rızaları alınmıştır.
} 
Aralık 2020 tarihinde bize iletilmiştir. Bu noktada, dersin projeye yönelik olarak kurgulanabilmesi adına, ders gününden önce proje koordinatörleri ile proje hakkında bir toplantı yapılmıştır. Bu toplantıda, projenin amacı üzerinde durulmuş, çalışma grupları ve görev dağılımları yapılarak görev tanımları belirlenmiştir. Ayrıca, yaklaşık 59 dakikalık videonun Youtube üzerinden transkripsiyonu alınarak transkripsiyon kontrolünün dersten önce gerçekleştirilmesi için, transkripsiyon, çeviri çalışmalarında daha az görev alabilecek iki öğrenciye gönderilmiştir. Çeviri aşamasında aktif rol alamayabileceğini belirten farklı iki öğrenciye de transkripsiyondan hareketle, terimleri belirleyerek ve terimlerin Türkçe karşılıklarını araştırarak terim çalışması yapma görevi verilmiştir. Böylelikle 8 Aralık 2020 günü proje çalışmasının başlayacağı ilk ders öncesinde altyazı çevirisi yapılacak videonun transkripsiyonu ve videoda kullanılan terimlere yönelik araştırma hazır olmuştur. Illk proje dersinde, çalışma grupları, görev tanımları, zaman çizelgesi, çalışma yöntemi netleştirilerek çeviri aşamasına geçilmiştir.

\subsection{Projenin Tanımı ve Çalışma Grupları}

Proje kapsamında Türkçe altyazı çevirisi gerçekleştirilmesine karar verilen serinin ilk konseri, 18 Ocak 1958 tarihinde New York Carnegie Hall'de gerçekleştirilen "What Does Music Mean?" adlı performanstır. 8 Aralık 2020 tarihinde başlayan projeye yönelik zaman çizelgesi oluşturma sürecinde, Vakıf yetkilileri bizleri serbest bırakarak, teslim tarihini bizlerin kendi ritmimize göre belirleyebileceğini ifade etmiştir. Bu doğrultuda, son ders günü 5 Ocak 2021 tarihinde proje kapsamında öğrencilere düşen işlerin tamamlanması öngörülmüştür.

Söz konusu projede, çeviri sürecine yönelik farklı görev tanımlarının belirlenerek grup çalışması yürütülmesine karar verilmiştir. Projenin sistemli bir şekilde yürütülmesi amacıyla; proje koordinatörü, editör, redaktör, çevirmen ve altyazı sorumlusu görevlerini barındıran bir çalışma yöntemine karar verilmiştir. Pym (2007) çeviri eğitiminde öğrencilere çevirmenin farklı profesyonel rollerine yönelik eğitim verilmesinin önemine vurgu yapmaktadır, bu ders kapsamında da, öğrencilere bu yönde bir eğitim verilmeye çalışılmaktadır. Öğrencilerin proje tabanlı eğitim modeli kapsamında farklı görevleri deneyimleyerek ekip çalışması içinde çeviriye yönelik çoklu becerileri kazanması hedeflenmektedir. Gerçek bir projeyi deneyimleyerek ekip çalışması yürüten öğrenciler, piyasa koşullarında bir çeviri projesinde yer almaya hazır duruma gelmektedir. 
Tablo 2

Proje Görev Dağılım Tablosu

\begin{tabular}{|c|c|c|c|}
\hline \multicolumn{2}{|c|}{ Proje Koordinatōrü 1} & \multicolumn{2}{|c|}{ Proje Koordinatörü 2} \\
\hline \multicolumn{2}{|c|}{$\downarrow$} & \multicolumn{2}{|r|}{$\downarrow$} \\
\hline \multicolumn{2}{|c|}{ Editör 1} & \multicolumn{2}{|c|}{ Editör 2} \\
\hline$\downarrow$ & $\downarrow$ & $\downarrow$ & $\downarrow$ \\
\hline Ceviri Grubu 1 & Çeviri Grubu 2 & Ceviri Grubu 3 & Çeviri Grubu 4 \\
\hline Redaktör 1 & Redaktör 2 & Redaktör 3 & Redaktör 4 \\
\hline Cevirmen 1 & Cevirmen 1 & Çevirmen 1 & Çevirmen 1 \\
\hline Çevirmen 2 & Çevirmen 2 & Cevirmen 2 & Cevirmen 2 \\
\hline Çevirmen 3 & Cevirmen 3 & Cevirmen 3 & Çevirmen 3 \\
\hline \multicolumn{2}{|c|}{$\downarrow$} & \multicolumn{2}{|c|}{$\downarrow$} \\
\hline \multicolumn{2}{|c|}{ Altyazı Grubu 1} & \multicolumn{2}{|c|}{ Altyazı Grubu 2} \\
\hline \multicolumn{2}{|c|}{ Altyazısı Sorumlusu 1} & \multicolumn{2}{|c|}{ Altyazısı Sorumlusu 2} \\
\hline \multicolumn{2}{|c|}{ Altyazı Görevlisi 1} & \multicolumn{2}{|c|}{ Altyaz Görevlisi 1} \\
\hline \multicolumn{2}{|c|}{ Altyaz Görevlisi 2} & \multicolumn{2}{|c|}{ Altyazı Görevlisi 2} \\
\hline \multicolumn{2}{|c|}{ Altyaz Görevlisi 3} & \multicolumn{2}{|c|}{ Altyazı Görevlisi 3} \\
\hline
\end{tabular}

Tablo 2'de sunulduğu gibi toplamda dört adet çeviri grubu oluşturulmuştur. Her çeviri grubunda üç adet çevirmen ve bir adet redaktör yer almaktadır. Iki editörün her biri iki tane çeviri grubundan sorumludur. Yukarıdaki bölümde sözü edilen, projenin genel olarak yürütülmesinden sorumlu iki proje koordinatörünün her biri, iki çeviri grubu ve onlarla bağlantılı bir editörle daha yakından çalışmaktadır. Çeviri gruplarının gerçekleştirdiği ve kontrol aşamaları tamamlanan çeviriler ise, altyazı formatına aktarılması amacıyla altyazı çalışma gruplarına teslim edilmektedir. ${ }^{5}$

Söz konusu görevlerin tanımlarının yapılması da projenin sistemli bir şekilde yürütülebilmesinde önemli bir adımdır. Proje koordinatörleri; çevrilecek metni, çeviri gruplarına eşit olarak paylaştırmakta, projenin zaman çizelgesini belirlemektedir. Tüm proje sürecinin takibini yapmaktadır. Gerekli zamanlarda dersin hocasıyla toplantı yaparak proje konusunda bilgi alışverişinde bulunmaktadır. Çeviri gruplarının redaktörleri, gruplarındaki çevirmenlere çevirisi yapılacak bölümleri eşit olarak paylaştırmaktadır. Çevirmenler, çevirilerini tamamladıktan sonra, çevirilerini gruplarının redaktörüne iletmektedir. Redaktörler, kendi gruplarındaki çevirmenlerden

\footnotetext{
${ }^{5}$ Bazı öğrenceler projede birden çok görev almaktadır.
} 
gelen çevirileri birleştirerek gerekli düzeltmeleri yapmaktadır. Düzeltmeleri yaparak birleştirdiği çevirileri tek dosya olarak ilgili editöre teslim etmektedir. Editör, her çalışma grubunun redaktörü tarafından ön okuması ve gerekli düzeltmeleri yapılmış metinleri birleştirerek son kontrolü yapmaktadır. Bu noktada dil düzeyinde ve terimlerde tutarlılık sağlanması önemlidir. Birleştirerek kontrolünü tamamladığı tek dosyayı proje koordinatörlerine ve dersin hocasına iletmektedir. Editörden gelen çeviriler, derste sınıf ortamında kontrol edilerek altyazı gruplarına teslim edilmektedir. Her altyazı grubu, iki çeviri grubuna ait son kontrolü gerçekleştirilmiş çevirinin, altyazı formatına aktarılmasından sorumludur. Altyazı sorumluları, kendi gruplarındaki altyazı görevlilerine eşit olarak çevirileri paylaştırmaktadır. Altyazısını tamamlayan altyazı görevlisi, dosyasını grubunun altyazı sorumlusuna iletmektedir. Grubunun altyazılarını birleştiren ve kontrolünü yapan altyazı sorumlusu dosyasını proje koordinatörlerine ve dersin hocasına iletmektedir. Altyazıların son kontrolü ise, Vakfa teslim edilmeden önce dersin hocası ve proje koordinatörleri tarafından gerçekleştirilmektedir. Söz konusu ekip çalışması bağlamında, öğrencilerin her biri ve eğitmen aktif konumda rol alarak çeviri eğitiminde sosyal yapılandırmacı bakış açısının (Kiraly, 2000) vurguladığı gibi bilgiyi iş birliğiyle, karşılıklı etkileşimle oluşturmaktadır.

Grup çalışma yönteminin ve görev tanımlarının netleşmesiyle, her çalışma grubunda görev alacak öğrenci isimleri dersin hocası tarafından koordinatörlere de danışılarak belirlenmiştir. Proje koordinatörleri, videoyu dört eşit parçaya ayırarak her grubun Türkçe altyazı çevirisini yapacağı dakika aralıklarını belirlemiştir. Ayrıca, proje takibine yönelik bir e-posta grubu oluşturulmuştur (tekmetyazarl@gmail), çevirmen tarafından redaktöre iletilen çeviri dosyası, redaktör tarafından editöre iletilen çeviri dosyası konusundaki e-postların sözü edilen adrese de gönderilerek, dersin hocasına ve proje koordinatörlerine de eşzamanlı bilgi verilmesi sağlanmıştır.

\section{Resim 1}

Proje Bülteni 1
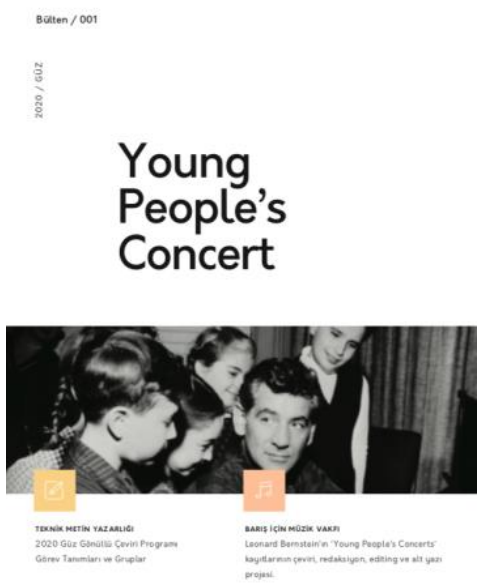
Sözü edilen projede benimsenen çalışma yöntemine ait tüm bilgiler, proje koordinatörü Melis Asya Meriç tarafından bir bültene aktarılmıştır. 8 Aralık 2020 tarihinde yapılan derste, öncelikli olarak proje detayları ve çalışma yöntemi bülten üzerinden öğrencilere aktarılmıştır. İki öğrenci tarafından kontrolü gerçekleştirilen videonun transkripsiyonu ve başka iki öğrenci tarafından hazırlanan terim listesi incelenmiştir. Söz konusu, terim çalışması videoda kullanılan İngilizce terimlerin belirlenerek Türkçe karşılıklarının verildiği bir terim listesi şeklindedir. Farklı çeviri grupları tarafından yürütülecek projede terim tutarlılığını sağlayabilmek amacıyla terimlerin karşılıkları çeviri sürecinden önce belirlenmeye çalışılmıştır. Ancak, her çeviri grubunun çeviri sürecinde terim çalışmasını detaylandırmasının, terimlerin bağlı olduğu alan ve tanımlarından hareketle terim karşılıklarını kontrol etmesinin gerekliliği üzerinde de durulmuştur. Çeviri sürecine başlamadan önce, çevirinin Vakıf tarafından belirlenen hedef kitlesi üzerinde de durulmuştur. Buna göre, hedef kitle, genel genç izleyici olarak tanımlanmıştır. Hedef, teknik müzik bilgisinin sıradan topluluklar tarafından da anlaşılır olmasıdır.

Videoda, orkestra şefi Leonard Bernstein orkestrayı yönetirken aralar vererek müziğin anlamı üzerine sohbet etmektedir. Müzikli bölümler dikkate alınarak, dört çeviri grubuna eşit bir şekilde çevrisi yapılacak dakikalar paylaştırılmaya çalışılmıştır. Buna göre; Grup 1'e 00:01 - 12:39, Grup 2'ye 12:45 - 23:39, Grup 3'e 23:42 - 31:58, Grup 4'e ise 32:01 - 49:06 dakika aralıkları verilmiştir. Her çeviri grubunun gerçekleştirdiği çeviriyi, en geç 14 Aralık 2020 tarihinde grubunun editörüne iletmesi istenmiştir.

\subsection{Altyazı Çevirisi}

Çeviri gruplarında görev alan öğrenciler, bulut tabanlı çeviri yönetim sistemlerinden Memsource'a hakim olduğundan, çeviri projesinin Memsource üzerinden yürütülmesinin proje yönetiminde kolaylık sağlayabileceği düşünülmüştür. Bu noktada her çeviri grubu Memsource üzerinde çalışmaya yönlendirilmiştir, ancak grupların kendi içlerinde istedikleri çalışma yöntemini de benimseyebilecekleri söylenmiştir.

Söz konusu projeyle, Teknik Metin Yazarlığı ders içeriğinde önceki yıllarda yer almayan altyazı çevirisi konusu gündeme gelmiştir. Bu noktada, bölüm öğretim elemanları Araştırma Görevlisi Dr. Fulya Marmara ve Araştırma Görevlisi Murat Onur Sabaz'dan ${ }^{6}$ genel bir altyazı çevirisi formasyonu için destek istenmiştir. 15 Aralık 2020 tarihindeki derste, Marmara ve Sabaz görsel-işitsel çeviri türlerinden yola çıkarak altyazı çevirisine yoğunlaştıkları bir sunum gerçekleştirmişlerdir. Sunumda, öncelikli olarak altyazı çevirisinin ne olduğu, özellikleri, altyazı çevirisinde dikkat edilecek noktalar ve benimsenebilecek yöntemler üzerinde durulmuştur. Alana yönelik genel bilgilendirmenin devamında Aegisub altyazı programı hakkında bir eğitim verilmiştir. Vakıf yetkilileri, altyazı çeviri dosyasının srt formatında teslimini talep etmiş ve srt

\footnotetext{
${ }^{6}$ Yıldız Teknik Üniversitesi Batı Dilleri ve Edebiyatları Fransızca Mütercim ve Tercümanlık Anabilim Dalı'nda 2018-2019 akademik yılında, Prof. Dr. Emine Bogenç Demirel yürütücülüğünde Dr. Fulya Marmara ve Murat Onur Sabaz, altyazı atölyeleri düzenlemiştir.
} 
dosyasını kendilerinin videoya gömebileceğini belirtmiştir. Aegisub programı ücretsiz olarak indirilebilmekte ve altyazı dosyası srt formatında oluşturulmaktadır. Çevirisi gerçekleştirilecek Youtube videosunun bilgisayara indirilmesi, indirilen videonun Aegisub altyazı programında açılması ve altyazıların yerleştirilmesi konularında uygulamalı olarak çalışılmıştır.

Çeviri gruplarının çevirilerini tamamlayarak ilgili editörlere teslim ettiği süreçte, altyazı çevirisi dersinin kazanımlarından hareketle, proje kapsamında benimsenen altyazı çevirisine yönelik kararları kapsayan bir altyazı yönergesi oluşturulmuştur. Söz konusu yönergede, ESIST (European Association for Studies in Screen Translation) bünyesinde hazırlanan kılavuzdan hareketle (Carroll \& Ivarsson, 1998), iyi altyazı çevirisi uygulamalarına yönelik olarak üzerinde durulan konular (Okyayuz, 2016, s. 90) proje kapsamında netleştirilmiştir. Buna göre;

- Çevirmen zaman ve yer kısıtının farkında olarak anlamı bozmayacak şekilde çeviride kısaltma yoluna gidebilir.

- Türkçe sözdizimine uyulmalıdır.

- Altyazılar, konuşmalarla eşzamanlı olarak ekranda görünmelidir.

- Görüntü değişikliğinden 1 saniye önce altyazı eklemekten kaçınılmalıdır.

- Yazı tipi okumayı zorlaştırmamalıdır; yazı tipi Ariel 17'dir.

- Altyazı genellikle beyaz renkle oluşturulur; bu çalışmada da beyaz renk tercih edilmelidir.

- Konuşmacının pozisyonuna göre metin konumlandırılabilir; genel olarak altta ve ortada olmalıdır.

- Gerekli durumlarda cümleler bölünmelidir ve izleyici için okuma süresinin yeterli olup olmadığı kontrol edilmelidir; karakter saniye arılığı CPS değeri en az 10, en fazla 20 olmalıdır.

Altyazı çevirisinde dikkat edilmesi gereken noktalama işaretlerine yönelik genel bilgilere de yönergede yer verilmiştir (Okyayuz, 2016, ss. 98-100);

- Noktalı virgül, parantez, köşeli ayraç, kesme imi ve tire mecbur olmadıkça kullanılmamalıdır.

- Virgül, nokta, iki nokta üst üstte, ünlem, soru işareti, üç nokta, yıldız işareti, tırnak işareti, büyük harf kullanımı ve eğik yazı kullanımı gerektiğinde kullanılır.

- Ünlem ve soru işaretlerinden önce bir boşluk bırakılmalıdır.

- Virgül, noktalı virgül, iki nokta üst üste ve noktadan sonra bir boşluk bırakılmalıdır.

- Parantez ve tırnak açmadan önce bir boşluk, kapattıktan sonra bir boşluk bırakılmalıdır.

- Sadece iki kişinin diyaloglarının olduğu sahnelerde konuşma çizgisi kullanılmalıdır. 
- Bir cümlenin devamı bir dahaki sahnede devam ediyorsa üç nokta konulmamalıdır.

Çeviri gruplarının çalışmaları sırasında bazı ortak çeviri kararlarının alınması gerekli olmuştur. Bazı özel durumlara yönelik çeviri kararları, Vakıf yetkilileriyle görüşülerek alınmıştır. Çevirisi yapılmaması gereken öğeler ve beste, senfoni, besteci isimlerinin çevirisi hakkında alınan kararlara söz konusu yönergede yer verilmiştir. Buna göre yönergede yer alan çeviri kararları şöyledir;

- Seyirci sesi gibi net duyulmayan dış seslerin alt yazı çevirisi yapılmayacaktır.

- Sözsüz Müzik için: $\delta$ Müzik $\delta$ kullanılmalıdır. Müziğin sahnede belirleyici olduğu durumlarda müzik köşeli parantez içinde tarif edilebilir.

- Alkış için: [Alkış Sesi] kullanılmalıdır.

- Anlam üreten tüm göstergeler (tablolar, besteci resimleri vb.) seyirciye aktarılmalıdır. Bu çeviriler italik yazı tipinde verilerek konuşma iletisinden farklı olduğu belli edilmelidir.

- Türkçe karşılığına ulaşılan senfoni, beste isimleri sadece Türkçe olarak altyazıya aktarılmalıdır. Türkçe karşılığına ulaşılamayan eserler ise orijinal şekliyle bırakılmalıdır.

- Besteci isimlerinin Türkçe yazımında farklılık varsa, Türkçe yazımı kullanılmalıdır.

- Türkçeye yerleşmiş müzik terimleri orijinal şekliyle korunmalıdır.

- Melodilerin çevirisinde Türkçede uygun karşılıklar bulunursa yerlileştirme yoluna gidilmelidir.

\section{Resim 2}

Proje Bülteni 2 


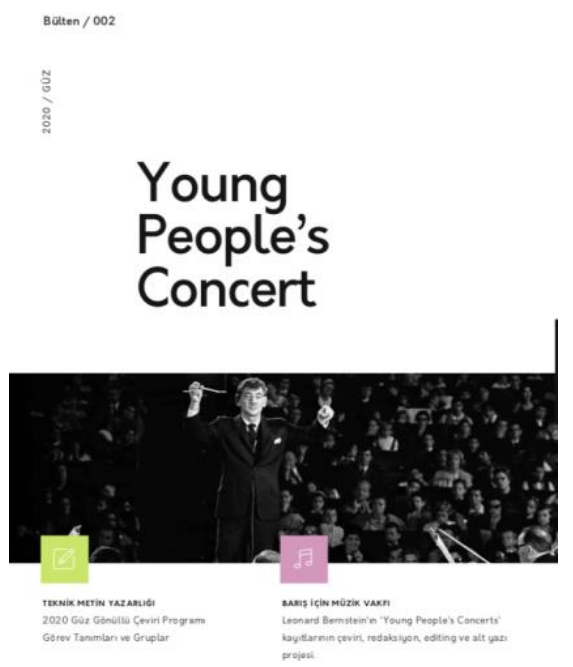

Altyazı çevirisine yönelik teknik bilgileri ve çeviri kararlarını kapsayan yönerge için proje koordinatörü Melis Asya Meriç ikinci bülteni hazırlamıştır. 15 Aralık 2020 tarihinde yapılan derste, söz konusu bültenin detayları öğrencilerle paylaşılmıştır.

\subsection{Altyazı Çevirisi Uygulaması}

Çeviri gruplarının redaktörlerinin, proje editörlerine ve koordinatörlerine Word formatında aktardıkları çeviri dosyaları 22 Aralık 2020 tarihinde yapılan derse kadar editörler ve koordinatörler tarafından kontrol edilmiştir. Bu kontrol aşamasında alınan ortak çeviri kararları yol gösterici olmuştur. 22 Aralık 2020 tarihli derste, Çeviri Grubu 1 ve Çeviri Grubu 2'nin; 29 Aralık 2020 tarihli derste ise Çeviri Grubu 3 ve Çeviri Grubu 4'ün çeviri dosyalarının sınıf ortamında son kontrolü gerçekleştirilmiştir. Çeviri kontrolü aşamasında, Word formatındaki Türkçe çeviri dosyaları ekrana yansıtılmıştır. Dakika bilgilerinin de yer aldığı Türkçe çeviri dosyalarının kontrolü kaynak metin olan videonun da eşzamanlı izlenmesiyle gerçekleştirilmiştir. Bu aşamada word formatındaki erek metinde yer alan dakika bilgilerine de dikkat edilerek altyazı formatına aktarım sürecine hazırlık yapılmaya çalışılmıştır.

Belirli koşullara yönelik olarak alınan çeviri kararlarına yönelik bazı örnekleri paylaşmak yerinde olacaktır. Çeviri çalışmasında senfoni ve beste isimlerinin Türkçe karşılıkları kullanılmıştır. Aşağıda görüldüğü üzere "Wild West" müzikleri Türkçeye "Vahşi Batı" müzikleri, Johann Strauss'un bestesi "The Blue Danube" ise Türkçeye "Mavi Tuna" olarak aktarılmıştır (Tablo 1).

Tablo 1

Senfoni ve beste isimlerinin çevirisine örnekler

\begin{tabular}{ll}
\hline $07: 14$ & $07: 14$ \\
{$[. .$.$] remember the piece we played$} & Başlangıçta çaldığımız parçayı \\
\hline
\end{tabular}


07:16 07:16

at the beginning [rhythm] Wild West piece hatırlayın [ritim] Vahşi Batı müziklerinden bir of music

parça

$\begin{array}{ll}\text { 11:15 } & \text { 11:15 } \\ \text { Johann Strauss wrote an awful lot of } & \text { Johann Strauss çok fazla vals yazmıştır } \\ \text { 11:17 } & 11: 17 \\ \text { waltzes and one of them goes like this } & \text { ve biri şöyledir [müzik] } \\ \text { 11:21 } & 11: 21 \\ \text { you know the name of this one [music] } & \text { Bunun adını biliyorsunuz değil mi? } \\ \text { 11:25 } & 11: 25 \\ \text { Right, The Blue Danube now maybe the } & \text { Evet. Mavi Tuna } \\ \text { 11:30 } & 11: 30 \\ \text { Danube river inspired Strauss to write } & \text { Belki de Strauss'un bu valsi yazarken ilham } \\ \text { 11:32 } & \text { kaynağı Tuna Nehri olmuştur diyebiliriz } \\ \text { that waltz I don't know I have my doubts } & 11: 32 \\ & \text { Bilemiyorum, emin değilim }\end{array}$

Çeviri çalışmasında, besteci isimlerinin Türkçe yazılışında farklılık olduğu durumlarda Türkçe yazılış benimsenmiştir. Rus besteci "Musorgski"nin isminin Türkçe kullanımı bu noktada örnek olarak verilebilir (Tablo 2).

\section{Tablo 2}

Besteci isimlerin yazılışına örnek

\begin{tabular}{ll}
\hline 29:23 & $29: 23$ \\
now one of the best pieces that paint & Şimdi kafanızdaki görüntüyü hayal etmenize \\
29:26 & yardımcı olacak \\
pictures is by a Russian composer called & $29: 26$ \\
29:29 & en iyi parçalardan biri Bir Sergiden Tablolar \\
Mussorgsky, he wrote a piece named & $29: 30$ \\
29:33 & Musorgski adında bir Rus besteci \\
Pictures at an Exhibition what & $29: 34$ \\
29:35 & tarafından yazılmıştır. \\
Mussorgsky did was to take a lot of & $29: 35$ \\
29:38 & Musorgski'nin yaptığı şey \\
pictures hanging on a wall at a museum & $29: 37$ \\
29:40 & müzede duvarda asılı olan tablolardan \\
and write music that he thought could & esinlenerek \\
29:43 & $29: 41$ \\
describe them & notalardan bir parça oluşturmak.
\end{tabular}

Müzik terimlerinin Türkçe çevirisinde ise, Türkçeye orijinal şekliyle yerleşmiş terimlerin orijinal kullanımının korunmasına karar verilmiştir. Bu bağlamda solo, düet, trio, triplet, quartet vb. terimler örnek olarak verilebilir. Aşağıda görüldüğü üzere bir 
müzik türü olan "boogi-woogie" terimi de orijinal şekliyle Türkçeye aktarılmıştır (Tablo $3)$.

Tablo 3

Müzik terimlerinin çevirisine örnek

\begin{tabular}{ll}
\hline $04: 54$ & $04: 54$ \\
this piece of boogie-woogie & Peki ya bu boogie-woogie? \\
\hline
\end{tabular}

Leonard Bersntein'ın, anlatımı esnasında kullandığı bazı melodiler için de Türkçede uygun karşılıklar bulunmaya çalışılmıştır. Buna göre "Olly olly and free" şarkısı melodisi de dikkate alınarak, "Yağ satarım bal satarım" şeklinde, "Nya nya nya" ise yine bağlam ve melodi dikkate alınarak "Eeeziiik eeezziiik" şeklinde Türkçeye aktarılmıştır (Tablo 4).

\section{Tablo 4}

Melodilerin çevirisine örnek

\begin{tabular}{|c|c|}
\hline $30: 06$ & $30: 06$ \\
\hline children playing in a park, and what & parkta oyun oynayan çocuklar \\
\hline $30: 09$ & $30: 09$ \\
\hline Mussorgsky did to make it sound like & Musorgski 'nin yaptığı şey \\
\hline $30: 11$ & $30: 12$ \\
\hline children playing was to imitate the way & çocukların kendi aralarında oyun \\
\hline $30: 14$ & oynarken kullandıkları \\
\hline children talk when they play games & $30: 21$ \\
\hline $30: 17$ & "Yağ satarım bal satarım" gibi cümleleri \\
\hline almost like singing you know when & $30: 24$ \\
\hline $30: 19$ & ya da birbirleriyle alay \\
\hline you go in a game olly olly and free & neredeyse şarkı söyler gibi bir melodiyle \\
\hline $30: 22$ & söyledikleri \\
\hline olly olly and free there's a kind of & $30: 31$ \\
\hline $30: 24$ & "Eeeziiik eeezziiik" kelimelerini taklit \\
\hline tune you're singing or when kids are & etmektir \\
\hline $30: 27$ & \\
\hline taunting each other making fun of each & \\
\hline $30: 29$ & \\
\hline other when they play and they go & \\
\hline $30: 31$ & \\
\hline Nya nya nya of Mussorgsky took & \\
\hline
\end{tabular}

Ders ortamında çeviri çalışmalarının paylaşılması ve sınıf ortamında son kontrolün gerçekleştirilmesi, farklı görevleri bulunan tüm öğrencilerin bilginin üretimine ve kontrolüne katılımı anlamında önem taşımaktadır. Sınıf ortamında son kontrolleri tamamlanan çeviri dosyaları, altyazı formatına aktarılması amacıyla altyazı gruplarına teslim edilmiştir. Buna göre, Çeviri Grubu 1 ve Çeviri Grubu 2 tarafından 
çevirisi gerçekleştirilen 00:01-23:39 dakika aralığının altyazı formatına aktarılmasından Altyazı Grubu 1, Çeviri Grubu 3 ve Çeviri Grubu 4 tarafından çevirisi gerçekleştirilen 23:42-49:06 dakika aralığının altyazı formatına aktarılmasından ise Altyazı Grubu 2 sorumlu olmuştur. Her altyazı grubunun sorumlusu, kendi çalışma grubundaki 3 öğrenciye altyazıya aktarılacak dakikaları paylaştırmıştır.

\section{Resim 3}

\section{Aegisub Altyazı Programı}

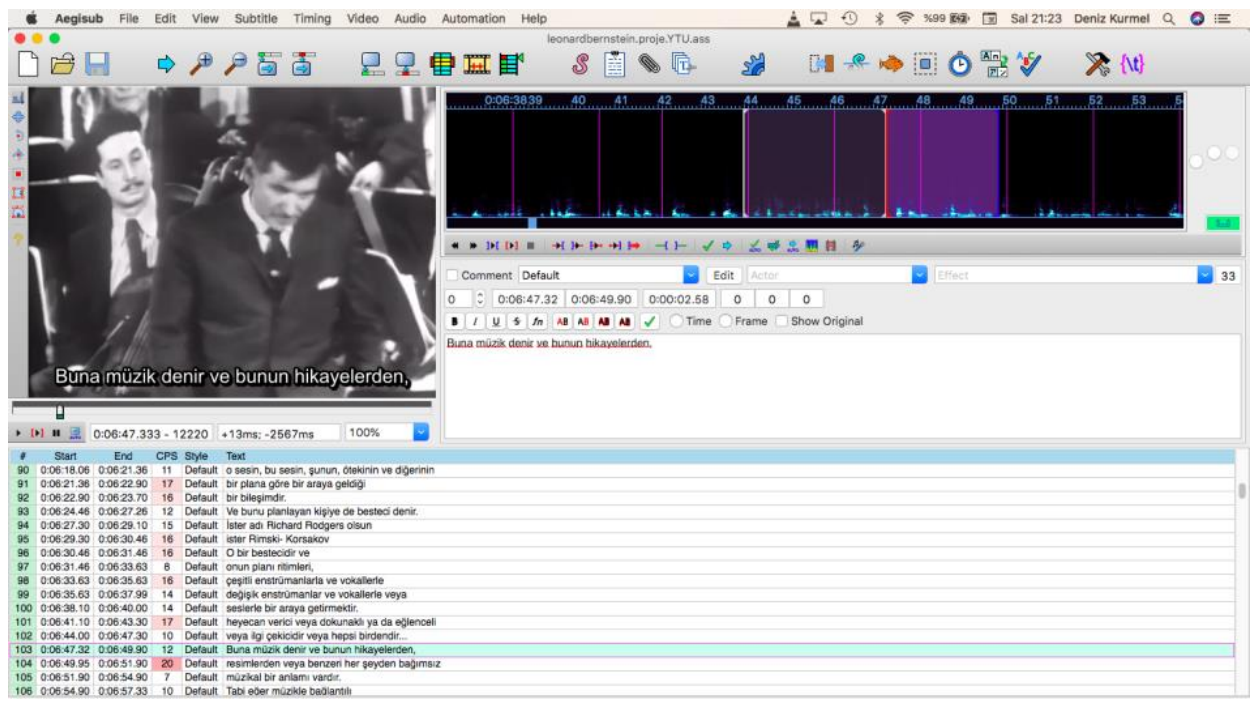

Altyazı görevlileri, Word formatında kendilerine teslim edilen kontrolü tamamlanmış çevirileri altyazı formatına Aegisub programı aracılığıyla aktarmışlardır. Vakıf tarafından Youtube adresi paylaşılan ve her öğrencinin çalışma esnasında bilgisayarına indirdiği kaynak video, Aegisub programıyla entegre bir şekilde çalışan VLC Player Video Oynatıcı Programıyla açılabilmektedir. Böylelikle Aegisub programına aktarılan altyazılar video üzerinden de görüntülenebilmektedir. Böylelikle altyazı görevlileri, konuşmaların başlangıç ve bitiş sürelerini ayarlayarak spotlama işlemi ile altyazı ve ses arasındaki uyumdan hareketle senkronlama işlemini de yapabilmektedir. Altyazısını tamamlayan altyazı görevlisi, srt formatındaki altyazı dosyasını grubunun altyazı sorumlusuna teslim etmektedir. Her grubun altyazı sorumlusu ise, kendisine teslim edilen srt dosyalarını birleştirerek kontrol etmektedir. Her iki altyazı grubunun sorumlusu, altyazı çeviri dosyalarını proje koordinatörlerine ve dersin hocasına iletmektedir. Son ders günü olan 5 Ocak 2021 tarihinde, sınıf ortamında, altyazı çevirileri, Aegisub altyazı programında ve VLC Player Video Oynatıcı Programında entegre bir şekilde açılarak son kontrole başlanmıştır. Bu son kontrolün tamamlanması, altyazı çeviri dosyaları Vakfa teslim edilmeden önce dersin hocası ve proje koordinatörleri tarafından gerçekleştirilmiştir. Son kontrolü tamamlanan altyazı çeviri dosyaları, 2020-2021 güz yarıyılı derslerinin sonunda, tek bir srt dosyası formatında Vakıf yetkililerine teslim edilmiştir. Vakıf, altyazı çeviri dosyasını videoya yerleştirmeden önce bir alan uzmanının kontrol aşamasından geçirmiştir. Bu aşamadan 
sonra ise Türkçe altyazı çevirisi bulunan videoyu uzaktan eğitim ders materyali olarak "Müzik Kültürü" dersleri kapsamında kullanmaya başlamıştır.

\section{Resim 4}

Gönüllü Sertifikası

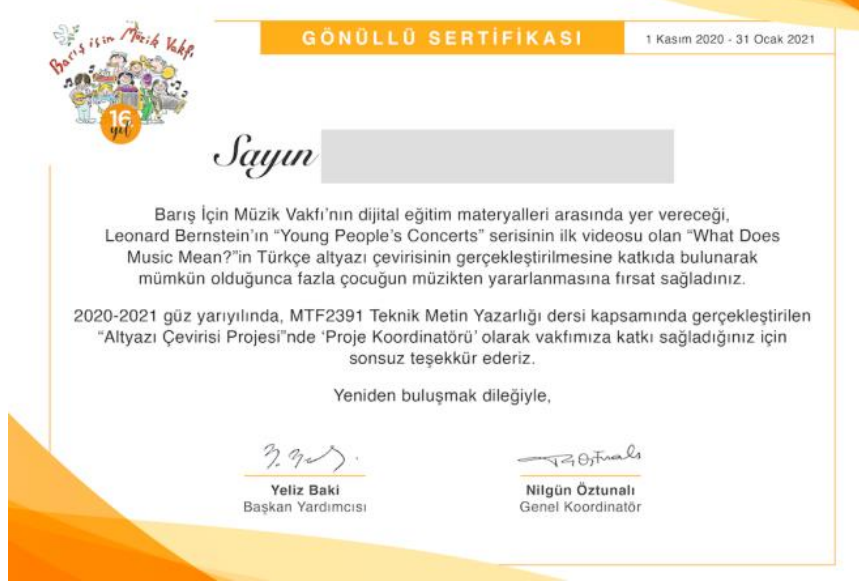

5 Ocak 2021 tarihinde yapılan son derse, Vakfın kurucularından Yeliz Baki ve Vakfın Genel Koordinatörü Nilgün Öztunalı katılarak, projenin yürütülmesi ve tamamlanması hakkında öğrencilerle görüşlerini paylaşmıştır. Ayrıca Vakıf yetkilileri, projede görev alan öğrencilere görev tanımlarını da belirttikleri “Gönüllü Sertifika"larını sunarak, çok sayıda çocuğun müzikten yararlanmasına fırsat sağladıkları için teşekkür etmiştir.

\section{Sonuç}

MTF2391 kodlu Teknik Metin Yazarlığı dersi kapsamında, Barış İçin Müzik Vakfıyla birlikte yürütülen altyazı çevirisi projesiyle, çeviri eğitiminde proje temelli yaklaşım benimsenmiştir. Gerçek bir çeviri projesinde, gerçek bir işverenle çalışma olanağı bulan öğrenciler, ders kapsamında aktif rol alarak çoklu öğrenme olanağını elde etmişlerdir. Buna göre, temel çeviri ve altyazı çevirisi becerilerini kazanmanın yanı sıra proje yönetimi, ekip çalışması, bilgi ve teknolojinin kullanımı gibi konularda da beceri kazanmışlardır.

Bu proje temelli ders kapsamında benimsenen sosyal yapılandırmacı bakış açısıyla (Kiraly, 2000), eğitmen ve öğrenciler işbirlikçi bir ortamda, bilginin karşılıklı olarak yaratılmasına katkı sağlamışlardır. Öğrenciler çeviriye yönelik farklı görevler alarak ve farklı beceriler kazanarak çevirinin çok boyutluluğunu deneyimlemişlerdir. Ekip çalışmasında, etkileşimli bir ortamda, gerçek bir çeviri sürecini deneyimleyerek sorun çözme becerisi kazanmışlardır. Bu ders kapsamında, gerçek bir çeviri proje çalışması etrafında şekillenen bir öğrenci güçlenmesinden bahsetmek mümkündür. 
Altyazı çevirisine yönelik olarak ise, öğrenciler altyazı çevirisine yönelik temel ilkeleri kazanırken, teknolojiyle entegre bir şekilde çalışarak altyazı çevirisi programlarında çalışma becerisini de elde etmişlerdir. Altyazı çevirisi projesi bağlamında, İngilizceden Türkçeye çeviri, öncelikle, çeviri grupları tarafından Word formatında dakika aralıkları belirtilerek gerçekleştirilmiştir. Sonrasında bu çeviriler sınıf ortamında kontrol edilmiş, kontrol sırasında altyazıların ekranda belirecekleri karelerin saptanması ve bunların bölümlenmesi üzerinde de durulmuştur. Bu aşamadan sonra ise, altyazı çevirisi grupları çevirileri Aegisub altyazı programına aktarmışlar ve altyazının ekranda belirdiği anı ve ekranda kalış süresini ayarlamışlardır. Bu noktada, Sánchez'in (2004) altyazı çevirisi ekip çalışma yönteminde söz ettiği süreçlerden, "ön çeviri-uyarlama-spotlama" sürecinin izlendiği söylenebilir. Bu süreçlerin izlenmesi, öğrencilerin altyazı çevirisine yönelik olarak da farklı görevleri deneyimlemesine olanak sağlamıştır.

\section{Resim 5}

\section{Altyazı Çevirisi Projesinin Görünürlüğü}

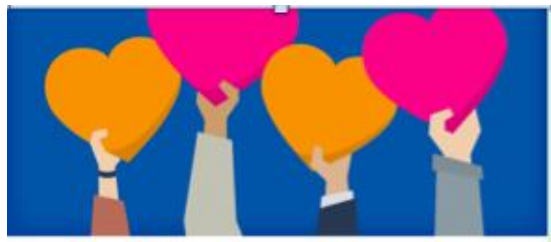

ŨNIVERSITELILER VAKFIMIZIN GÖNÖLLERI OLUYOR!

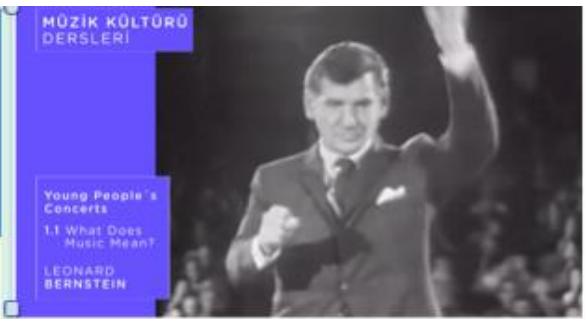

MÜZIK KÜLTÜRÖ DERSLERI KAPSAMINDA MATERYAL GELISTIRMEYE

DEVAM EDIYORUZ.

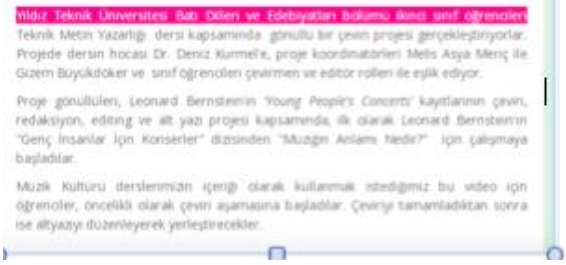

Her öğrencinin, projede aldığı görev belirtilerek Vakıf tarafından hazırlanan ve öğrencilere verilen "Gönüllü Sertifikaları", öğrencilerin gelecekte çeviri piyasasında alacakları görev anlamında önem taşımaktadır. Ayrıca, Vakıf kendi web sayfasında her ay yayımladığı bültenlerin Aralık 2020 tarihli sayısında, proje sürecinden gönüllülük bağlamında söz etmiştir. Ocak 2021 bülteninde ise, projenin tamamlandığını, altyazı çevirisi gerçekleştirilen videonun ders materyali olarak kullanılmaya başladığını haberleştirilmiştir. Projenin görünürlüğüne destek olan bu paylaşımlarla, öğrencilerin gerçek bir çeviri projesinde görev almasına yönelik motivasyonları daha da artmıştır.

Çeviri eğitiminde, farklı proje tabanlı derslerin kurgulanması ve geliştirilmesi, çeviri alanının çok boyutluluğunun deneyimlenmesine ve çeviriye yönelik farklı becerilerin kazanılmasına olanak sağlayacaktır. 


\section{Kaynakça}

Ak, B. (01 Ekim 2021). Tarihçe ve anlayış. https://www.barisicinmuzik.org/tarihce.

Barış İçin Müzik Vakfı. (01 Ekim 2021). Aylık e-bültenler. https://www.barisicinmuzik.org/aylik-ebulten.

Bernstein, L. (04 Aralık 2020). Young people's concerts - 1.1 What Does Music Mean [Video]. https://www.youtube.com/watch?v=_2OisC_XfF4.

Bogenç Demirel, E., \& Sabaz, M. O. (2021). Teknik çeviri alanında yaratıcı pratik yöntemler: YÜciTA projesi. Frankofoni, 38, 37-48.

Bogenç Demirel, E., \& Görgüler, Z. (2015). Pratique réflexive sur la traduction collaborative en ligne en Turquie. 100 \% user-made translation. Revue Parallèles, 27 (1), 137-148.

Canım Alkan, S. (2020). Çeviri eğitiminde teknoloji destekli proje tabanlı simülasyon yöntemi: İstanbul Üniversitesi örneği. Turkish Studies - Education, 15(6), 3919-3937. https://dx.doi.org/10.47423/TurkishStudies.45977.

Carroll, M., \& Ivarsson, J. (1998). Code of good subtitling practice. ESIST European Association for Studies in Screen Translation. https://www.esist.org/wpcontent/uploads/2016/06/Code-of-Good-Subtitling-Practice.PDF.pdf.

Chaume, F. (2013). The turn of audiovisual translation: New audiences and new Technologies. Translation Spaces, 2, 105-123.

Chiaro, D. (2013). Audiovisual translation. C. A. Chapelle (Ed.), The Encyclopedia of Applied Linguistics içinde (ss. 1050-1060). Wiley-Blackwell.

Diaz-Cintas, J., \& Anderman, G. (Ed.) (2009). Audiovisual translation language transfer on screen. Palgrave Macmillan.

Galán-Mañas, A. (2011). Translating authentic technical documents in specialised translation classes. The Journal of Specialised Translation, 16, 109-125. https://www.jostrans.org/issue16/art_manas.pdf.

Gambier, Y. (2006). Multimodality and audiovisual translation. EU-High-Level Scientific Conference Series. MuTra 2006 - Audiovisual translation scenarios: Conference proceedings.

https://www.euroconferences.info/proceedings/2006_Proceedings/2006_Gambier_Yves .pdf.

Gambier, Y. (2007). Réseaux de traducteurs/interprètes bénévoles. Meta, 52(4), 658-672.

Gambier, Y. (2008). Recent developments and challenges in audiovisual translation research. D. Chiaro, C. Heiss \& C. Bucaria (Ed.), Between Text and Image: Updating research in screen translation içinde (ss. 11-33). John Benjamins Publishing Company.

Gambier, Y. (2012). Traduction: Des métiers différents, un processus commun. http://docplayer.fr/1838018-Traduction-des-metiers-differents-un-processuscommun.html.

Gerald, A., Brusaw, C., \& Oliu, W. (2015). Handbook of technical writing. Eleventh Edition. Bedford/St. Martin's.

Gouadec, D. (2002). Profession: traducteur. La Maison du dictionnaire. 
Gouadec, D. (2003). Notes on translator training (replies to a questionnaire). A. Pym, C. Fallada, J. R. Biau \& J. Orenstein (Ed.), Innovation and e-learning in translator training. Reports on online symposia içinde (ss. 11-19). Universitat Rovira i Virgili.

Insan Hakları Evrensel Beyannamesi, (1949). https://inhak.adalet.gov.tr/Resimler/Dokuman/10122019101449insanhaklaribeyanname si.pdf

Kiraly, D. (2000). A social constructivist approach to translator education. Empowerment from theory to practice. St. Jerome Publishing.

Kiraly, D. (2005). Project-based learning: a case for situated translation. Meta, 50(4), 1098-1111. https://doi.org/10.7202/012063ar.

Mackenzie, R. (2004). The competencies required by the translator's roles as professional. K. Malmkjaer (Ed.), Translation in undergraduate degree programmes içinde (ss. 31-38). John Benjamins. https://doi.org/10.1075/btl.59.04mac.

Olvera-Lobo, M., Castro-Prieto, M. R., Quero-Gervilla, E., Muñoz-Martín, R., Muñoz-Raya, E., Murillo Melero, M., Robinson, B., Senso-Ruiz, J. A., Vargas-Quesada, B., \& Domínguez López, C. (2005). Translator training and modern market demands. Perspectives: Studies in translatology, 13(2), 132-142.

Okyayuz, A. Ş. (2016). Altyazı çevirisi. Siyasal Kitabevi.

Okyayuz, A. Ş., \& Kaya, M. (2016). Altyazı çevirisi eğitimi için bir model önerisi. International Journal of Languages, Education and Teaching, 4 (2), 257-275. https://dx.doi.org/10.18298/ijlet.601.

Okyayuz, A. Ş., \& Kaya, M. (2017). Görsel-işitsel çeviri eğitimi. Siyasal Kitabevi.

Pérez González, L., \& Saraeva, Ş. (2012). Non-professionals translation and interpreting. The Translator, 18(2), 149-165.

Pym, A. (2007). Translation technology and training for intercultural dialogue: What to do when your translation memory won't talk with you. https://usuaris.tinet.cat/apym/online/translation/2007_tm_talk_to_me.pdf.

Sánchez, D. (2004). Subtitling methods and team-translation. P. Orero (Ed.), Topics in Audiovisual Translation içinde (ss. 9-17). John Benjamins Publishing Company.

YTÜ Bologna Bilgi Sistemi. (01 Eylül 2021). Yıldız Teknik Üniversitesi'nde Bologna Süreci. http://www.bologna.yildiz.edu.tr/index.php.

YTÜ Bologna Bilgi Sistemi. (01 Eylül 2021). Teknik Metin Yazarlığı Dersi. http://www.bologna.yildiz.edu.tr/index.php?r=course/view\&id=5855\&aid=8. 